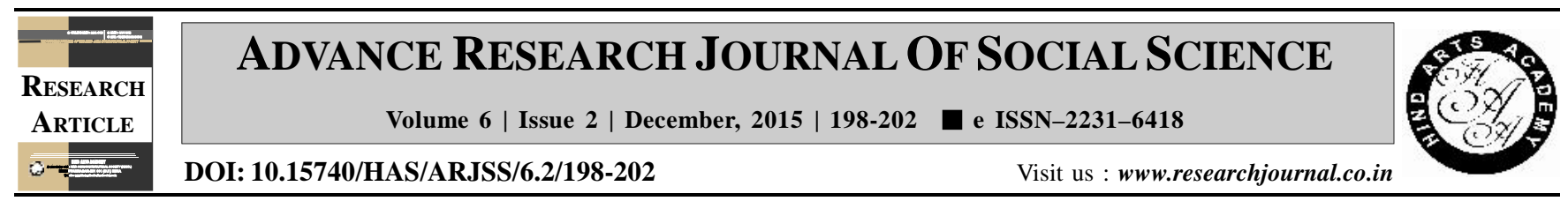

\title{
Participation of husband in selected household activities of Mehsana district of Gujarat
}

Jiju Vyas* and Minaxi Baraiya

Junagadh Agricultural University, JUNAGADH (GUJARAT) INDIA

(Email : vyasjiju1807@gmail.com)

\section{ARTICLE INFO :}

$\begin{array}{lll}\text { Received } & : & 18.08 .2015 \\ \text { Revised } & : & 30.10 .2015 \\ \text { Accepted } & : & 11.11 .2015\end{array}$

KEY WORDS :

Women's role, Participation, Sociological improvement, Women's work

HOW TO CITE THIS ARTICLE :

Vyas, Jiju and Baraiya, Minaxi (2015). Participation of husband in selected household activities of Mehsana district of Gujarat. Adv. Res. J. Soc. Sci., 6 (2) : 198-202.

*Author for correspondence

\begin{abstract}
Women's role in nation's development is unparalleled. The position of women in society is indicative of its civilization. Women constitute perhaps the most powerful resource that is yet balance in favorable sociological improvements. Women's work is grueling, virtually unending but also creative, productive and responsible. They are the creators and sustainers of the family. Women have a great responsibility to play as a home maker. They have now an added major role that of as a wage earner. Technical and industrial advancement on one side have made life easy, while on the other side, the role of the husband has also changed considerably. The research objective was to know the participation of husband in household activities. Survey and interview schedule was used on the selected husbands of Mehesana district of Gujarat. 150 samples were selected for the present study from different talukas of Mehesana district. The result concluded that young husband's participation was more than old husband. The difference was not vast but it would be noted that young generation took more interest in domestic responsibilities and managed there challenge efficiently.
\end{abstract}

